\title{
TINJAUAN PENERAPAN PENGAMPUNAN PAJAK (TAX AMNESTY) DALAM MENINGKATKAN KESADARAN DAN KEPATUHAN WAJIB PAJAK ORANG PRIBADI PADA KPP PRATAMA JAKARTA - SUNTER.
}

\author{
Ratiyah \\ Email: ratiyah.rty@bsi.ac.id, \\ Lukman Sri Muchtar \\ Email: lukmansrimuchtar@yahoo.co.id \\ NO.289 Cawang Jakarta Timur 13630
}

Manajemen Pajak, Fakultas Ekonomi dan Bisnis Universitas Bina Sarana Informatika

\begin{abstract}
In order to maximize taxes, the Government carried out reforms by implementing policies that were driven by the smaller possibility of hiding assets outside the territory of the Republic of Indonesia. One part of the current tax reform is the government policy regarding the Tax Amnesty program. This study aims to find out how to increase awareness and compliance of Taxpayers and to find out the achievement of Tax Amnesty results. The results of this study are that the awareness and compliance of individual taxpayers in the tax amnesty program is quite high because the government seeks to improve several sectors, namely by conducting socialization from the government itself and from the tax service office. The results of achieving Tax Amnesty are quite significant even though there are several obstacles. It means that the Tax Amnesty program is planned in the long term and was managed well and the State will get an increase in tax revenues in a short time.
\end{abstract}

Keywords: Tax Amnesty, Taxpayer

\section{ABSTRAK}

Dalam rangka memaksimalkan pajak, Pemerintah melakukan reformasi dengan menerapkan kebijakan untuk terobosan yang didorong oleh semakin kecilnya kemungkinan untuk menyembunyikan harta kekayaan di luar wilayah Negara kesatuan Republik Indonesia. Salah satu bagian dari reformasi perpajakan saat ini dengan adanya kebijakan pemerintah mengenai program Tax Amnesty. Penelitian ini bertujuan mengetahui bagaimana meningkatkan kesadaran dan kepatuhan Wajib Pajak dan untuk mengetahui pencapaian hasil Tax Amnesty. Hasil dari penelitian ini yaitu Kesadaran dan kepatuhan wajib pajak orang pribadi dalam program tax amnesty cukup tinggi ini dikarenakan pemerintah berupaya untuk meningkatkan beberapa sektor yaitu dengan melakukan sosialisasi baik dari pemerintah itu sendiri maupun dari kantor pelayanan pajak dan hasil pencapaian penerapan Tax Amnesty cukup signifikan meski masih ada beberapa kendala. Yang artinya jika program Tax Amnesty direncanakan dalam jangka panjang dan dikelola dengan baik, Negara akan memperoleh peningkatan penerimaan pajak dalam waktu singkat.

Kata kunci: Tax Amnesty, Wajib Pajak

\section{PENDAHULUAN}

\section{Latar Belakang}

Sebagai negara berkembang, Indonesia membutuhkan penerimaan negara dalam jumlah besar untuk menopang pembiayaan pembangunan nasional dalam segala bidang seperti pembangunan bidang ekonomi, sosial budaya dan hukum. Dalam sistem pemungutan pajak Indonesia menganut sistem selfassessment di mana wajib pajak (WP) diberi hak penuh dalam menghitung, membayar dan melaporkan sendiri kewajiban perpajakannya. Penerapan pemungutan pajak seperti ini memiliki keuntungan di mana kantor pajak tidak akan disulitkan dalam mengitung dan mendata jumlah pajak yang seharusnya dibayar oleh wajib pajak. Pajak adalah sumber penerimaan negara yang terbesar dibanding dengan sumber lainnya, oleh karena itu pemerintah terusmenerus berusaha mengoptimalkan pajak setiap tahunnya. Dengan tujuan untuk mengoptimalkan penerimaan pajak tersebut, pemerintah dan Direktorat Jenderal Pajak (DJP) sebagai lembaga yang bertugas untuk pemungutan pajak melakukan berbagai upaya dalam meningkatkan kesadaran dan kepatuhan wajib pajak orang pribadi guna meningkatkan penghasilan negara untuk itu perlu dilakukannya strategi diantara nya melakukan program amnesti pajak. Amnesti pajak adalah program pengampunan yang 
diberikan oleh pemerintah kepada Wajib Pajak (WP) meliputi penghapusan pajak yang seharusnya terutang, penghapusan sanksi administrasi perpajakan, serta penghapusan sanksi pidana di bidang perpajakan atas harta yang diperoleh pada tahun 2015 dan sebelumnya yang belum dilaporkan dalam SPT, dengan cara melunasi.

Hasil penelitian dari Ngadiman dan Huslin (2015), yang menunjukkan bahwa tax amnesty berpengaruh positif signifikan terhadap kepatuhan wajib pajak. Jika penerapan tax amnesty semakin tinggi, maka kepatuhan wajib pajak juga semakin tinggi. Dan hasil peelitian dari Istighfarin dan Fidiana (2018) menemukan bahwa implementasi tax amnesty belum berjalan secara optimal karena belum adanya standarisasi informasi antar otoritas pajak yang satu dengan yang lainnya, KPP satu dengan yang lainnya, masih belum memadainya jumlah pegawai yang bertugas melayani tax amensty, kurangnya kualitas sistem antrian pelayanan tax amnesty, dan masih belum intensifnya sosialisasi tax amnesty untuk wajib pajak. Sedangkan hasil penelitian dari Pravasanti (2018) menunjukkan bahwa kebijakan tax amnesty di Indonesia dinilai berhasil dan berdampak terhadap perekonomian negara.

\section{Permasalahan}

adalah:

Permasalahan dalam penelitian ini

1. Bagaimana upaya meningkatkan kesadaran dan kepatuhan wajib pajak orang pribadi di KPP Pratama Jakarta - Sunter?

2. Berapa pencapaian hasil penerimaan pajak setelah program amnesti pajak terhadap wajib pajak orang pribadi dikantor KPP Pratama Jakarta - Sunter?

\section{Tujuan Penelitian}

Penelitian ini bertujuan untuk:

1. Mengetahui tingkat kepatuhan dan kesadaran wajib pajak dalam melaksanakan kewajiban perpajakan.

2. hasil pencapaian penerapan Tax Amnesty

\section{TINJAUAN PUSTAKA \\ Definisi Pajak}

Pajak bagi sebagian orang kata ini dapat memunculkan perasaan tidak nyaman. Sekilas kata tersebut memang terasa menyeramkan, baik untuk kalangan masyarakat kelas atas maupun kelas bawah. Tak sedikit yang berpikir, apa-apa kena pajak, dimana-mana kena pajak, siapapun kena pajak. Oleh karena itu sebenarnya apa itu pajak? Mengapa kita harus bayar pajak? Dan untuk apa nantinya uang pajak yang kita bayarkan tersebut? Begitu mungkin perihal pertanyaan masyarakat mengenai pajak.

Menurut Undang-Undang Ketentuan Umum dan Tata Cara Perpajakan (UU KUP) Nomor.28 Tahun 2007 pasal 1 ayat 1."Pengertian Pajak adalah kontribusi wajib pajak kepada negara yang terutang oleh orang pribadi atau badan yang bersifat memaksa berdasarkan Undang - Undang, dengan tidak mendapatkan imbalan secara langsung dan digunakan untuk keperluan negara bagi sebesar -besarnya kemakmuran rakyat".

Menurut Muzammil (2016 :2) pajak adalah: "Sejumlah uang yang wajib dibayarkan seseorang warga negara kepada pemerintahnya.kontribusi ini bersifat memaksa dan membayar pajak tidak akan mendapatkan imbalan secara langsung. Dengan kata lain, uang yang dibayar kan pembayar pajak kepada pemerintah akan dikembalikan dalam bentuk pembangunan fasilitas-fasilitas umum".

Definisi Pajak menurut Putra (2017:11) telah dijelaskan di dalam Undang- undang Nomor 16 tahun 2009 tentang perubahan keempat atas Undang-Undang nomor 6 tahun 1983 tentang Ketentuan Umum dan Tata Cara Perpajakan pada pasal 1 ayat 1.

"Pajak adalah kontribusi wajib kepada Negara yang terutang oleh orang pribadi atau badan yang bersifat memaksa berdasarkan Undang-Undang, dengan tidak mendapatkan imbalan secara langsung dan digunakan untuk keperluan Negara bagi sebesar-besarnya kemakmuran rakyat".

Menurut Andriani (2017:3), menerangkan bahwa: "Pajak adalah iuran kepada negara (yang dapat dipaksakan) yang terutang oleh yang wajib membayarnya menurut peraturan -peraturan dengan tidak mendapat prestasi kembali, yang langsung dapat ditunjuk dan yang gunanya adalah untuk membiayai pengeluaran -pengeluran".

\section{Fungsi Pajak}

Menurut Putra (2017:12) Fungsi

pajak Pada dasarnya pajak mempunyai peran yang cukup besar kehidupan bangsa. Adapun beberapa fungsi pajak. Di antaranya adalah sebagai berikut: 
1. Fungsi Anggaran (budgetair)

disebut sebagai fungsi pajak atau fungsi finansial (fiscal function) yaitu suatu fungsi dimana pajak dipergunakan sebagai alat untuk memasukan dana secara optimal ke kas berdasarkan undang -undang perpajakan yang berlaku.

2. Sebagai Alat Pengatur

fungsi ini mempunyai pengertian bahwa pajak dapat dijadikan sebagai alat mencapai tujuan tertentu. Sebagai contoh ketika pem erintah berkeinginan untuk melindungi kepentingan petani dalam negeri, pemerintah dapat menetapkan pajak $t$ ambahan seperti pajak impor atau bea masuk atas kegiatan ini impor komoditas tertentu

3. Sebagai Alat Penjaga stabilitas

pemerintah dapat dapat menggunakan sarana perpajakan untuk stabilitas ekonomi. Sebagai barang-barang impor dikenakan pajak agar produksi dalam negeri dapat bersaing. Untuk menjaga stabilitas nilai tukar rupiah dan menjaga agar defisit perdangan tidak semakin melebar.

4. Fungsi Retribusi Pendapatan

Pemerintah membutuhkan dana untuk membiayai pembangunan infrastruktur, seperti jalan raya dan jembatan . Kebutuhan akan dana itu dapat dipenuhi melalui pajak yang hanya dibebankan kepada mereka yang mampu membayar pajak. Namun demikian, Infrastruktur yang dibangun tadi dapat juga dimanfaatkan oleh mereka yang tidak mampu membayar pajak.

\section{Subjek dan Objek Pajak Penghasilan Orang Pribadi}

\begin{tabular}{cl} 
Menurut & \multicolumn{2}{c}{ Undang-UndangNomor } \\
36 Tahun 2008 & subjek pajak \\
penghasilan meliputi: &
\end{tabular}

1. Orang Pribadi

2. Warisan yang belum terbagi sebagai satu keastuan, menggantikan yang berhak

3. Badan yaitu sekumpulan orang dan atau modal yang meruoakan keasatuan baik yang melakukan usaha maupun yang tidak melakukan usaha maupun yang tidak melakukan usaha milik negara atau firma kongsi, koperasai, dana pensiunan, persekutuan, perkumpulan, yayasan organisasi massa, organisasi social politik, atau organisasi lainnya, Lembaga dan bentuk badan lainnya yang termasuk kontrak investasi kolektif dan usaha tetap.
4. Bentuk Usaha Tetap (BUT) yakni bentuk usaha yang dipergunakan oleh orang pribadi yang tidak bertempat tinggal di Indonesia, orang pribadi yang berada di Indonesia tidak lebih dari 183 hari dalam jangka waktu 12 bulan dan badan yang tidak didirikan dan tidak bertempat kedudukan di Indonesia, yang dapat tempat manajemen perusahaan, cabang perusahaan kantor perwakilan, pabrik , gudang, dll.

Objek pajak penghasilan orang pribadi Muzammil (2016:26). adalah pengahasilan dan pendapatan yang diterima oleh wajib pajak yang diperolehnya dalam dan luar negeri sebagai harta kekayaan berbentuk apapun. Kriteria penghasialan sesuai dengan $\mathrm{PPh}$ pasal 21 dan PPh pasal 26 antara lain:

1. penggantian atau imbalan berkenaan dengan pekerjaan atau jasa diterima atau diperoleh termasuk gaji, upah , tunjangan, honorarium, komisi, bonus, grafikasi, uang pension atau imbalan dalam bentuk lainnya kecuali ditentukan lain dalam Undang-Undang Pajak Penghasilan.

2. Hadiah dari undian atau pekerjaan atau kegiatan dan penghargaan.

\section{Sejarah Pengampunan Pajak}

Sejarah menurut Siahaan (2017:3) terjadinya dasar pertimbangan pengampunan pajak yang pernah berlaku di Indonesia antara lain:

1. Pengampunan Pajak Berdasarkan Penetapan Presiden Republik Indonesia Nomor 5 Tahun 1964.

Dasar Pertimbangan Pemberlakuan Pengampunan Pajak Penetapan Presiden Republik Indonesia Nomor 5 Tahun 1964 terbit dengan pertimbangan bahwa untuk kepentingan Revolusi Nasional Indonesia dan Pembangunan Nasional Semesta Berencana pada umumnya serta untuk memperlancar pelaksanaan Deklarasi Ekonomi tanggal 28 Maret 1963 dan penyerahan segala dana, daya dan tenaga pada khusunya, perlu diberikan pengampunan pajak terhadap modal yang berada dalam masyarakat yang belum pernah dikenakan pajak. Pertimbangan ini didasarkan pada kenyataan bahwa terdapat masyarakat yang memiliki dan menikmati, menguasai, dan mepergunakan modal yang selama ini belum pernah dikenakan Pajak Perseroan, Pajak Pendapatan, dan Pajak Kekayaan. Untuk itu sudah selayaknya mereka 
diharuskan membayar tebusan dari jumlah pajak menurut peraturan-peraturan fiscal sebenarnya terutang kepada negara.

2. Pengampunan Pajak Berdasarkan Keputusan Presiden Republik Indonesia Nomor 26 tahun 1984.

Dasar pertimbangan pemberlakuan pengampunan pajak berdasarkan Keputusan Presiden Republik Indonesia Nomor 26 Tahun 1984 dengan dasar pertimbangan sebagai berikut:

a. Bahwa dengan Undang-Undang Nomor 6 Tahun 1983 tentang Ketentuan Umum dan Tata Cara Perpajakan, Undang-Undang Nomor 7 Tahun 1983 tentang Pajak Penghasilan, dan Undang-Undang Nomor 8 Tahun 1983 tentang Pajak Pertambahan Nilai Barang dan Jasa dan Pajak Penjualan atas Barang Mewah, telah diciptakan system perpajakan baru guna meningkatkan peran masyarakat dalam pembiayaan negara dan pembangunan nasional.

b. Bahwa untuk melaksanakan system perpajakan baru tersebut dengan baik diperlukan adanya pangkal tolak yang bersih berlandaskan kejujuran dan keterbukaan dari masyarakat; dan

c. Bahwa dalam rangka upaya untuk mencapai hal tersebut diatas dipandang perlu untuk memberikan pengampunan dibidang perpajakan.

3. Pengampunan Pajak Tahun 2016

Dasar pertimbangan munculnya

Pengampunan Pajak Tahun 2016 yaitu:

a. Pembangunan nasional Negara Kesatuan Republik Indonesia yang bertujuan untuk memakmurkan seluruh rakyat Indonesia yang merata dan berkeadilan, memerlukan pendanaan besar yang besumber utama dari penerimaan pajak.

b. Untuk memenuhi kebutuhan penerimaan pajak yang terus meningkat, diperlukan kesadaran dan kepatuhan masyarakat dengan mengoptimalkan semua potensi dan sumber daya yang ada.

c. Kesadaran dan kepatuhan masyarakat dalam melaksanakan kewajiban perpajakan masih perlu ditingkatkan karena terdapat harta, baik didalam maupun diluar negeri yang belum atau belum seluruhnya dilaporkan dalam Surat Pemberitahuan Tahunan Pajak penghasilan. d. Untuk Meningkatkan penerimaan negara dan pertumbuhan perekonomian serta kesadaran dan kepatuhan masyarakt dalam pelaksanaan kewajiban perpajakan, perlu menerbitkan kebijakan Pengampunan Pajak; serta

e. Berdasarkan pertimbangan sebagaimana dimaksud dalam huruf a sampai dengan huruf $d$, perlu membentuk Undang-undang tentang Pengampunan Pajak.

\section{Perbandingan Pengampunan Pajak Yang Pernah Berlaku Di Indonesia}

Pengampunan pajak pada dasarnya sudah ada sejak Indonesia merdeka yaitu pengampunan pajak tahun 1964, pengampunan pajak tahun 1984 dan pengampunan pajak tahun 2016 . Perbandingan pengampunan pajak bisa dilihat dari dasar hukum, objek pajak, subjek pajak, sifat pengampunan, kewajiban pajak yang dicakup, sarana, dasar pengenaan, tarif, sanksi bila tidak mengikuti, batas waktu permohonan pengampunan pajak fasilitas pengampunan pajak, konsekuensi bila diberikan pengampunan pajak, dan penagihan.

$$
\text { Menurut Siahaan }
$$

perbandingan ketentuan pengampunan pajak adalah sebagai berikut:

Tabel.1 Perbandingan Pengampunan Pajak Yang Pernah Berlaku Sejak Indonesia Merdeka.

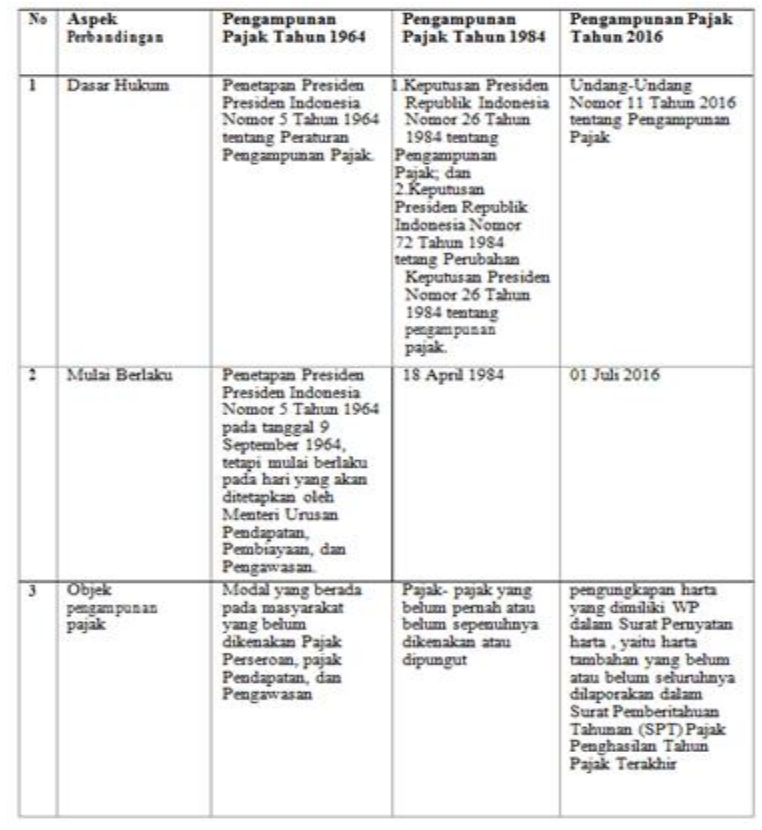


Account: Vol 6 No 1 Ratiyah, Lukman Sri Muchtar
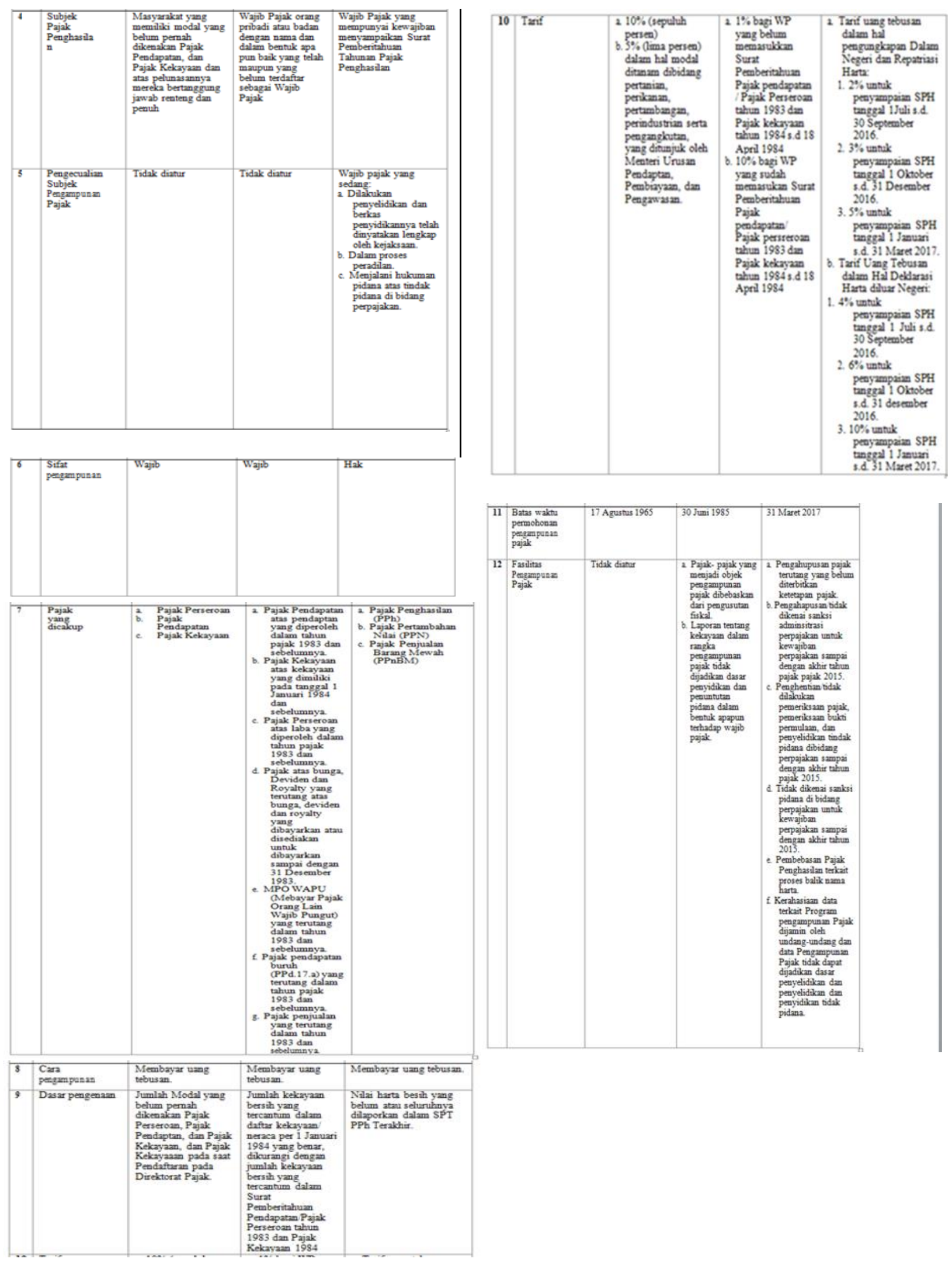


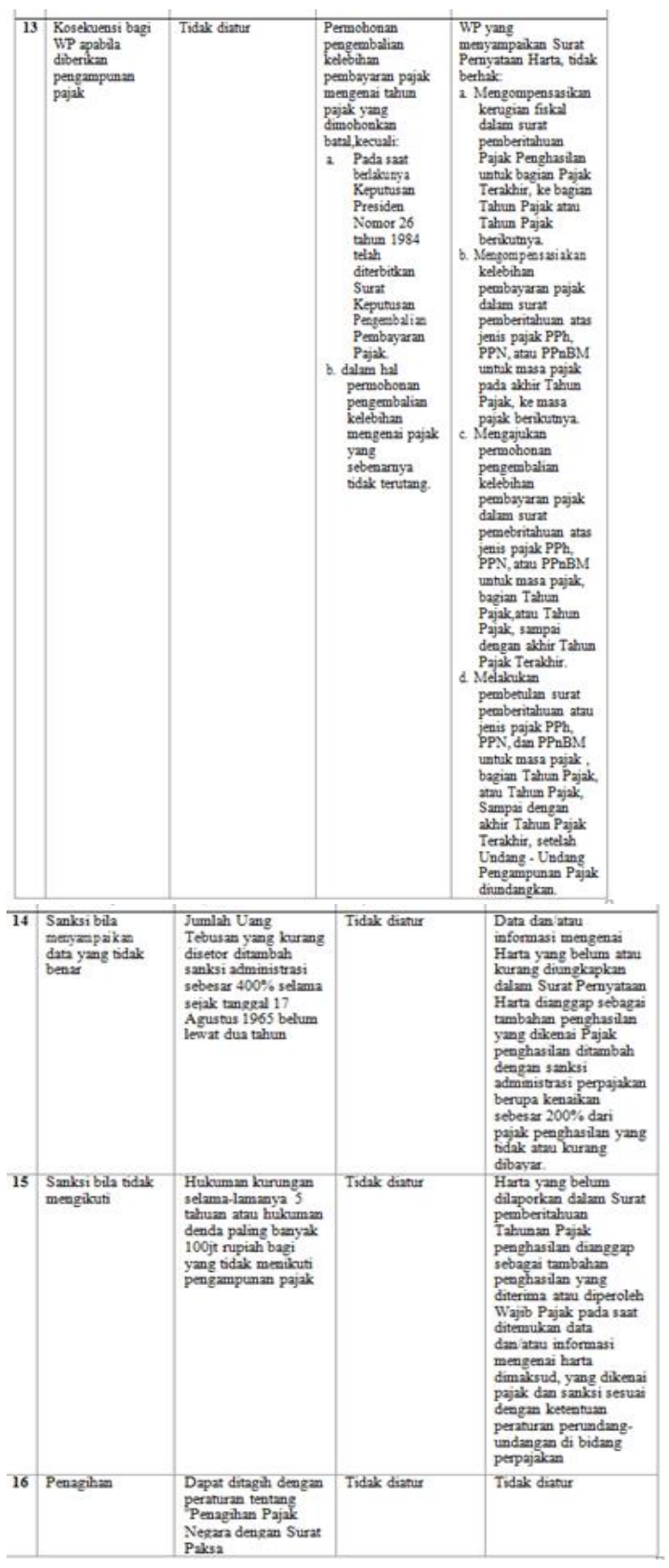

\section{Latar Belakang Amnesti Pajak}

Menurut Indra (2017:117) Latar belakang munculnya amnesti pajak berawal dari pertumbuhan ekonomi nasional dalam beberapa tahun terakhir cenderung mengalami perlambatan yang berdampak pada turunnya penerimaan pajak dan juga telah mengurangi ketersediaan likuiditas dalam negeri yang sangat diperlukan untuk meningkatkan pertumbuhan ekonomi di Indonesia. Di sisi lain banyak harta warga negara Indonesia yang ditempatkan di luar wilayah Negara Kesatuan Republik Indonesia, baik dalam bentuk likuid maupun dalam bentuk likuiditas dalam negeri yang dapat mendorong pertumbuhan ekonomi nasional.
Permasalahannya adalah sebagian dari harta yang berada di luar wilayah Negara Kesalahan Republik Indonesia tersebut belum belum dilaporkan oleh pemilik harta dalam surat pemberitahuan pajak penghasilan sehingga terdapat konsekunsi perpajakan sehingga terdapat konsekuensi yang mungkin timbul apabila dilakukan pembadingan dengan harta yang telah dilaporkan dalam surat pemberitahuan tahunan pajak penghasilan yang telah bersangkutan. Hal ini merupakan salah satu faktor yang menyebabkan para pemilik harta tersebut merasa ragu untuk membawa kembali atau mengalihkan harta mereka dan untuk menginvestasikannya dalam kegiatan ekonomi di Indonesia. Untuk itu perlu diterapkannya langkah khusus dan terobosan kebijakan untuk mendorong pengalihan harta kedalam wilayah Indonesia sekaligus memberikan keamanan bagi warga Negara Indonesia yang ingin mengalihkan dan mengungkapkan harta yang dimilikiknya dalam bentuk pengampunan pajak. Terobosan kebijakan berupa pengampunan pajak atas penghasilan harta ini juga didorongnya oleh semakin kecilnya kemungkinan untuk menyembunyikan kekayaan di luar wilyah Indonesia karena semakin transparan sektor keuangan global dan meningkatnya intensitas pertukaran informasi antar negara.

\section{Definisi Pengampunan Pajak}

Tax Amnesty merupakan kebijakan pemerintah di bidang perpajakan yang memberikan pengahapusan pajak yang seharusnya terutang dengan membayar tebusan dalam jumlah tertentu.

Menurut PMK No.118/PMK.03/2016. "Tax Amnesty adalah penghapusan pajak yang seharusnya terutang, tidak dikenai sanksi administrasi perpajakan dan pidana dibidang perpajakan, dengan cara mengungkapkan Harta dan membayar Uang Tebusan sebagaimana diatur dalam Undang-Undang Pengampunan Pajak".

Pengampunan atau pengurang pajak menurut Putra (2017:120) adalah "Penghapusan pajak terutang, penghapusan sanksi administrasi perpajakan, penghapusan sanki pidana pada bidang perpajakan dengan uang tebusan. Penghapusan pajak ini objeknya bukan hanya yang di luar negeri, tetapi juga yang berasal dari dalam negeri yang laporan nya tidak diberikan secara benar".

Pengampunan pajak menurut Faisal (2016:3) adalah "Sebuah program penghapusan 
pajak yang seharusnya terutang, yang berlaku secara terbatas (limitatif waktu berlakunya), dengan tidak dikenakan sanki administrasi perpajakan (baik berupa denda, bunga, dan kenaikan) dengan cara mengukapkan harta dan utang yang belum terungkap selama ini, baik yang pernah terlaporakan dalam tahun-tahun sebelumnya (persyaratan minimal untuk tahun pajak 2015) dan baru diungkapkan wajib pajak karena baru mulai terdaftar saat implementasi Undang-Undang Nomor 11 Tahun 2016 tentang pengampunan pajak ini diberlakukan (tanpa perlu melaporkan SPT tahunan 2015 dan sebelumnya), dangan cara membayar kepada kas negara uang yang disebut tebusan".

Menurut Suharno (2018:2) tentang pengampunan pajak adalah penghapusan pajak yang seharusnya terutang, tidak dikenai sanksi administrasi perpajakan dengan cara mengungkapkan Harta dan membayar Uang Tebusan sebagai mana yang diatur dalam Undang-Undang ini. Sedangkan definisi Undang-Undang Nomor 11 Tahun 2016 Pengampunan Pajak"adalah pengahapusan pajak yang seharusnya terutang, tidak dikenai sanksi administrasi perpajakan dan sanksi pidana dibidang perpajakan, dengan cara mengungkap harta dan membayar uang tebusan sebagaimana diatur dalam Undang-Undang tentang Pengampunan Pajak".

\section{Tujuan Dan Keuntungan Amnesti Pajak}

Tujuan Pengampunan Pajak Menurut Undang-Undang Nomor 11 Tahun 2016 pasal 2 yaitu :

1. Mempercepat pengalihan harta, dan restrukturisasi ekonomi melalui pengalihan harta, yang antara lain akan berdampak terhadap peningkatan likuiditas domestik, perbaikan nilai tukar rupiah, penurunan suku bunga, dan peningkatkan investasi.

2. Mendorong reformasi perpajakan menuju sistem perpajakan yang lebih berkeadilan serta perluasan basis data perpajakan yang lebih valid, komprehensif, dan terintegritas.

3. Meningkatkan penerimaan pajak, yang antara lain akan digunakan untuk pembiayaan pembangunan.

Keuntungan program amnesti pajak menurut Faisal (2016:4) yang diberikan oleh pemerintah yang telah disetujui oleh parlemen adalah sebagai berikut:

a. Penghapusan pajak yang seharusnya terutang b. Tidak dikenakan sanksi administrasi pajak dan sanksi pidana perpajakan.

c. Tidak dilakukan pemeriksaan, pemriksaan bukti permulaan adanya tindak pidana perpajakan, dan bahkan penyidikan adanya tindak pidana di bidang perpajakan.

d. Penghentian proses pemeriksaan, pemeriksaan bukti permulaan tidak pidana perpajakan dan penyidik adanya tindak pidana perpajakan.

e. Jaminan kerahasiaan dan pengampunan pajak yang tidak dapat dijadikan dasar penyelidikan dan tindakan pidana apapun.

f. Pembebasan pajak penghasilan (PPh) untuk harta tambahan yang masih diatas namakan pihak lain (nominee) hingga 31 desember 2017.

Dengan diberlakukan nya undangundang pengampunan pajak ini maka masyarakat yang memanfaatkan akan mendaptkan jaminan kepastian hukum, rasa keadilan berbagai proteksi atau fasilitas yang melekatk dalam program pengampunan pajak nasional ini demi kepentingan bangsa dan negara. Nasionalitas seluruh anak bangsa dituntut dalam program ini demi terwujudnya transparansi dan menyongsong pemberlakuan Automatic Exchange Of Information (AEOI) yang sudah mulai diberlakukan di seluruh dunia per September 2017. Artinya wajib pajak tidak bisa lagi menyembunyikan hartanya di otoritas pajak karena adanya keterbukaan informasi ini dari pihak-pihak terkait.

\section{Subjek Dan Objek Pengampunan Pajak}

Menurut Indra (2017:123) Setiap Wajib Pajak berhak mendapatkan pengampunan pajak. Akan tetapi, dalam hal ini hanya Wajib Pajak yang mempunyai Surat Pemberitahuan Tahunan Pajak Penghasilan baik yang sudah memiliki NPWP maupun yang belum ber NPWP. Oleh karena itu untuk Wajib Pajak yang semata-mata hanya diwajibkan melakukan pemotongan atau pemungutan pajak seperti bendaharawan pemerintah tidak berhak mendapatkan amnesty pajak. Sedangkan bagi Wajib Pajak yang belum ber NPWP, caranya harus mendaftarkan terlebih dahulu untuk meperoleh NPWP di Kantor Pelayanan Pajak yang bersangkutan.

Menurut Peraturan Direktur Jenderal Pajak PER-11/PJ/2016 subjek pengampunan pajak meliputi:

1. Wajib Pajak yang mempunyai kewajiban menyampaikan Surat Pemberitahuan Tahunan Pajak Penghasilan 
2. Orang pribadi seperti petani, nelayan, pensiunan, tenaga kerja Indonesia atau subjek pajak warisan yang belum terbagi,yang jumlahnya penghasilannya pada Tahun Pajak Terakhir dibawah Penghasilan Tidak Kena Pajak (PTKP) dapat tidak menggunakan haknya untuk mengikuti Pengampunan Pajak.

3. Warga Negara Indonesia yang tidak bertempat tinggal di Indonesia lebih dari 183 hari dalam jangka waktu 12 bulan dan tidak mempunyai penghasilan dari Indonesia merupakan Subjek Pajak luar negeri dan dapat tidak menggunkan haknya untuk mengikuti pengampunan pajak.

Menurut Faisal (2016:59) Subjek Pengampunan Pajak adalah "wajib pajak orang pribadi atau badan dan memperoleh NPWP serta memiliki kewajiban menyampaikan SPT tahunan PPh berhak mendapatkan pengampunan pajak, kecuali wajib pajak yang sedang dilakukan penyelidikan dan berkas penyidikannya telah dinyatakan lengkap oleh kejaksaan, sedang dalam proses peradilan, atau sedang menjalani pidana, atas tindak pidana dibidang perpajakan".

Objek dalam Pengampunan Pajak meliputi nilai harta yang diungkapkan dalam Surat Pernyataan untuk Pengampunan Pajak.

Objek Pengampunan Pajak Menurut Faisal (2016:60) adalah"kewajiban perpajakan yang belum sepenuhnya diselesaikan oleh wajib pajak, yang terepresentasi dalam harta yang belum pernah dilaporkan dalam SPT tahunan $\mathrm{PPh}$ terakhir. Pengampunan pajak diberikan kepada wajib pajak mengungkapan harta yang dimilikinya dalam surat pernyataan".

Subjek dan Objek menurut UndangUndang Nomor 11 Tahun 2016 pasal 3 tentang pengampunan pajak adalah :

1. Setiap wajib pajak berhak mendapatkan pengampunan pajak.

2. Pengampunan pajak sebagaimana dimaksud pada ayat (1) diberikan kepada wajib pajak melalui pengungkapan harta yang dimilikinya dalam surat pernyataan.

3. Dikecualikan dari ketentuan sebagaimana dimaksud pada ayat (1) yaitu wajib pajak yang sedang

a. Dilakukan penyelidik dan berkas penyididikan nya telah dinyatakan lengkap oleh kejaksaan. b. Dalam prose peradilan.

c. Menjalani hukuman pidana

4. Pengampunan pajak sebagaimana dimaksud pada ayat (1) meliputi pengampunan atas kewajiban perpajakan sampai dengan akhir yang belum atau belum sepenuhnya diselesaikan oleh wajib pajak.

5. Kewajiban perpajakan sebagaimana dimaksud pada ayat (4) terdiri atas kewajiban

a. Pajak penghasilan

b. Pajak pertambahan nilai atau pajak pertambahan nilai dan penjualan atas barang mewah.

Dalam hal ini yang bisa memanfaatkan pengampunan pajak adalah:

1. Wajib pajak orang Pribaadi

2. Wajib pajak badan

3. Wajib pajak yang bergerak dibidng usaha mikro dan menengah (UMKM) orang pribadi atau badan yang belum menjadi wajib pajak.

\section{Tarif Uang Tebusan Dalam Pengampunan Pajak}

Berdasarkan Undang-Undang Nomor 11

Tahun 2016 pasal 4 tentang pengampunan pajak, tarif uang tebusan yang dibayar oleh wajib pajak sebagai berikut:

1. Tarif uang tebusan atas harta yang berada di dalam wilayah Negara Kesatuan Republik Indonesia atau harta yang berada di luar wilayah Negara Kesatuan Republik Indonesia dan diinvestasikan di dalam wilayah Negara Kesatuan Republik Indonesia dalam jangka waktu singkat 3 (tiga) tahun terhitung sejak dialihkan, adalah sebesar:

a. $2 \%$ (dua persen) untuk periode penyampai Surat Pernyataan pada bulan pertama sampai dengan akhir bulan ketiga sejak Undang-Undang ini mulai berlaku.

b. 3\% (tiga persen) untuk periode penyampaian Surat Pernyataan pada bulan keempat terhitung sejak UndangUndang ini mulai berlaku sampai dengan tanggal 31 Desember 2016.

c. 5\% (lima persen) untuk periode penyampaian Surat Pernyataan terhitung sejak tanggal 1 Januari 2017 sampai dengan tanggal 31 Maret 2017.

2. Tarif Uang Tebusan atas harta yang berada diluar wilayah Negara Kesatuan Republik Indonesia dan tidak dialaihkan ke dalam wilayah Negara Kesatuan Republik Indonesia adalah sebesar: 
a. 4\% (empat persen) untuk periode penyampaian Surat Peryataan pada bulan pertama sampai dengan akhir bulan ketiga terhitung sejak Undang-Undang ini mulai berlaku.

b. $6 \%$ (enam persen) untuk periode penyampaian Surat Pernyataan pada bulan keempat terhitung sejak UndangUndang ini berlaku sampai dengan tanggal 31 Desember 2016.

c. $10 \%$ (sepuluh persen) untuk periode penyampaian Surat Pernyataan terhitung sejak 1 Januari 2017 sampai dengan tanggal 31 Maret 2017.

3. Tarif Uang Tebusan bagi Wajib Pajak yang peredarannya usahanya sampai dengan Rp4.800.000.000,00(empat miliar delapan ratus juta rupiah) pada tahun pajak terakhir adalah sebesar:

a. $0,5 \%$ (nol koma lima persen) bagi Wajib Pajak yang mengungkapkan nilai harta sampai dengan Rp10.000.000.000,00 (sepuluh miliar rupiah) dalam Surat Pernyataan.

Untuk periode penyampaian Surat Pernyataan pada bulan Pertama sejak UndangUndang ini mulai berlaku sampai dengan tanggal 31 Maret 2017.

\section{Cara Menghitung Uang Tebusan Dalam Pengampunan Pajak}

Dasar pengenaan uang tebusan Menurut Putra (2017:132) dihitung berdasarkan nilai harta bersih yang belum atau belum seluruhnya dilaporkan dalam SPT PPh terakhir. Sedangkan yang dimaksud dengan nilai harta bersih adalah harta tambahan yang belum pernah dilaporkan SPT PPh Terakhir dikurangi dengan utang yang terkait dengan perolehan Harta Tambahan tersebut, besarnya Uang Tebusan dihitung dengan cara mengalikan tatif dengan dasar uang tebusan.

Contoh :

Wajib pajak A hanya memiliki harta yang berada di dalam wilayah Negara Kesatuan Republik Indonesia. Dalam Surat Pemberitahuan Tahunan Pajak Pengahasilan Tahunan pajak 2015 (SPT PPh Terakhir) wajib pajak melaporkan:
a. Nilai Harta
:Rp. $15.000 .000 .000,00$
b. Nilai Utang
Rp. $\quad 5.000 .000 .000,00$
c. Nilai Harta Bersih
:Rp. $10.000 .000 .000,00$

Harta Bersih = Harta Tambahan (HT) - Utang Terkait HT

Uang Tebusan $=$ Tarif $\times$ Dasar Pengenaan Uang Tebusan

Dalam surat pernyataan yang disampaikan pada periode bulan pertama sampai akhir bulan ketiga terhitung sejak Undang-Undang ini berlaku, diketahui bahwa:

Dengan demikian dasar pengenaan Uang Tebusan adalah:

a. Nilai Harta
b. Nilai Utang
c. Nilai Harta Bersih

Dengan demikian dasar pengenaan Uang Tebusan adalah:

\section{Rp. $14.000 .000 .000,00-\operatorname{Rp} 10.000 .000 .000,00=\operatorname{Rp} .4 .000 .0000 .000,00$}

Penghitungan uang tebusan: tarif pada periode bulan pertama sampai dengan akhir bulan ketiga terhitung sejak Undang-Undang Pengampunan Pajak berlaku 2\%. Dasar pengenaan Uang Tebusan adalah Rp. 4.000.000.000,00 uang tebusan yang harus dibayar:

$\begin{array}{ccc}2 \% & \mathrm{x} & \mathrm{Rp} .4 .000 .000 .000,00 \\ \text { Rp.80.000.000,00 }\end{array}$

\section{METODE PENELITIAN}

Penelitian ini menggunakan metode kualitatif dengan pendekatan eksploratif deskriptif. Kotler dan Keller (2006) menyatakan bahwa pendekatan eksploratif adalah metode penelitian yang bertujuan menghimpun informasi awal yang akan membantu upaya menetapkan masalah dan merumuskan hipotesis. Pengertian pendekatan deskriptif adalah metode penelitian yang bertujuan memaparkan (mendeskripsikan) sesuatu hal. Sehingga dapat disimpulkan bahwa pendekatan ini bertujuan 
untuk mendalami mengenai kebijakan tax amnesty di Indonesia. Bahan penelitian dan informasi berasal dari data sekunder yang berasal dari penggalian informasi dari berbagai sumber, bahan seminar, media masa, media elektronik, dan lain-lain serta didukung pula dengan kajian pustaka.

\section{HASIL DAN PEMBAHASAN}

Dalam meningkatkan peminat masyarakat dalam ikut program pemerintah terutama Tax Amnesty, KPP Jakarta - Sunter melakukan strategi sebagai berikut :

1. Segera Lakukan Sosialisasi

Sebagaimana dinyatakan Dirjen Pajak bahwa kesadaran membayar pajak datangnya dari diri sendiri, maka pelayanan yang dialakukan KPP Pratama Jakarta Sunter menanamkan pengertian dan pemahaman tentang Pengampuanan Pajak bisa diawali dari lingkungan KPP Pratama itu sendiri, sehingga masyarakat yang sekiranya kurang paham bisa bertanya kepada petugas yang terkait dan melakukan sosialisai kepada mayarakat agar memberikan pengarahan yang tepat dan akurat. Dengan tingginya intensitas informasi yang diterima oleh masyarakat, maka dapat secara perlahan merubah pola pikir (mindset) masyarakat tentang pajak ke arah yang positif. Beragam bentuk sosialisasi bisa dikelompokkan berdasarkan: metode penyampaian, segmentasi maupun medianya.

2. Memberikan Kemudahan Kepada Semua Wajib pajak Dan Tingkatkan Mutu Pelayanan Kepada Wajib Pajak Dalam Melakukan Tax Amnesty .

Pelayanan yang berkualitas merupakan pelayanan yang dapat memberikan kepuasan kepada Wajib Pajak dan tetap dalam batas memenuhi standar pelayanan yang dapat dipertangung jawabkan serta harus dilakukan secara konsisten dan kontinyu, ini merupakan hal yang ditanamkan kepada pelayanan KPP Pratama Jakarta - Sunter . KPP Pratama Jakarta - Sunter terus menerus meningkatkan efisiensi administrasi dengan menerapkan sistem dan administrasi yang handal dan pemanfaatan teknologi yang tepat. Pelayanan berbasis komputerisasi merupakan salah satu upaya dalam penggunaan. Teknologi Informasi yang tepat untuk memudahkan pelayanan terhadap Wajib Pajak.
3. Memberikan Rasa Saling Percaya, Aman Dan Jaminan Hukum.

Antara Kantor Pelayanan Pajak dan Wajib Pajak terutama nya harus memberikan Rasa saling percaya, aman, dan jaminan hukum kepada wajib pajak guna memberikan kesadaran kepada Wajib Pajak bahwa program Pengampunan Pajak sejatinya adalah untuk kepentingan bersama dalam membangun bangsa.

4. Memberikan Pemahaman Melalui Jalur Pendidikan Khususnya Pendidikan Perpajakan.

Pendidikan diharapkan dapat mendorong individu kearah yang positif dan mampu menghasilkan pola pikir yang positif yang selanjutnya akan dapat memberikan pengaruh positif sebagai pendorong untuk melaksanakan kewajiban membayar pajak. Hal ini sangat perlu dilakukan terutama oleh Kantor Pelayanan Pajak Pratama Sunter.

\section{Hasil Pencapaian Penerapan Tax Amnesty Di KPP Pratama Jakarta Sunter.}

Pencapaian Tax Amnesty di KPP Pratama Jakarta Sunter memang pada mulanya kurang mencapai target dari yang diharapkan namun dengan adanya sosialisasi dari pemerintah dan turut serta Direktorat Jenderal Pajak KPP Pratama Jakarta - Sunter dalam pencapaian dalam program pemerintah khususnya Tax Amnesty membuat cukup berhasil.

Berikut pencapaian Tax Amnesty KPP Pratama Jakarta - Sunter periode 2016 - 2017:

Tabel.2 Hasil Pencapaian Pengampunan Pajak Di KPP Jakarta-Sunter

\begin{tabular}{|l|c|c|c|c|}
\hline \multicolumn{5}{|c|}{ Hasil Pencapaian Tax Amnesty KPP Pratama Jakarta - Sunter } \\
\hline Tahun & $\begin{array}{c}\text { Uang Tebusan } \\
\text { Pengampunan } \\
\text { Pajak }\end{array}$ & $\begin{array}{c}\text { Setor Pasal } \\
\text { 8(3)d UU } \\
\text { Pengampunan } \\
\text { Pajak }\end{array}$ & $\begin{array}{c}\text { Realisasi } \\
\text { Tax } \\
\text { Amnesty } \\
\text { Jumlah } \\
\text { Bayar }\end{array}$ & \\
\hline 2016 & 1.136 .656 .573 .547 & 1.701 .852 .905 & 1.138 .358 .426 .452 & \\
\hline 2017 & 115.228 .112 .823 & 13.207 .598 .354 & 128.435 .711 .177 & \\
\hline Jumlah & 1.251 .884 .686 .370 & 14.909 .451 .259 & 1.266 .794 .137 .629 & \\
\hline
\end{tabular}

Sumber : KPP Pratama Jakarta - Sunter

Dari table I diketahui bahwa pencapaian Tax Amnesty di KPP Pratama Jakarta - sunter sangat signifikan, yaitu mencapai uang tembusan Rp. 1.136.656.573.547 pada tahun 
2016 dan Rp. 115.228.112.823 ditahun 2017 dengan total perolehan sebanyak 1.266.794.137.629 dan tercatat setor untuk pasal 8 ayat 3 undang-undang pengampunan amnesty pajak total keseluruhan sebanyak 14.909.451.259 dengan jumlah yang ikut serta dalam Tax Amnesty sebanyak 10.254 wajib pajak, menjadi salah satu pencapaian terbaik yang dilakukan kantor pelayanan pratama di Indonesia dengan hasil yang memuaskan, diharapakan untuk kedepanya masyarakat bisa terus antusias dalam membayar kewajiban pajak guna untuk membangun bangsa.

\section{KESIMPULAN DAN SARAN}

1. Kesadaran dan kepatuhan wajib pajak orang pribadi dalam program tax amnesty cukup tinggi ini dikarenakan pemerintah berupaya untuk meningkatkan beberapa sektor yaitu dengan melakukan sosialisasi baik dari pemerintah itu sendiri maupun dari kantor pelayanan pajak.

2. Setelah adanya program pengampunan pajak, perolehan pencapaian pengampunan pajak yaitu mencapai uang tembusan $\mathrm{Rp}$. 1.136.656.573.547 pada tahun 2016 dan Rp. 115.228.112.823 ditahun 2017 dengan harga total perolehan sebanyak 1.266.794.137.629 dan tercatat setor untuk pasal 8 ayat 3 undang - undang pengampunan amnesty pajak total keseluruhan sebanyak 14.909.451.259 dengan jumlah yang ikut serta dalam tax amnesty sebanyak 10.254 jiwa. Dalam hal ini penerimaan negara bertambah cukup pesat guna membangun pembangunan nasional.

\section{Saran}

Setelah menyusun kesimpulan tersebut diatas, penulis ingin menyampaikan beberapa saran yaitu:

1. Dengan melihatnya masih ada beberapa kendala dalam program pengampunan pajak yang dialami Wajib Pajak sebaiknya Dirjen Pajak meningkatkan sosialisi terlebih dahulu kepada wajib pajak sebelum program itu dilaksanakan bukan hanya dilakukan setelah program tersebut berjalan untuk mengurangi ketidak pemahaman Wajib Pajak dalam program pengampunan pajak.

2. Dengan penerimaan dari uang tebusan dan antusias Wajib Pajak dalam mengikuti program pengampunan pajak yang sudah cukup besar dibanding pengampunan pajak yang sudah pernah dilaksanakan sebelumnya, tidak berarti KPP menjadi puas diri dengan hasil yang diperoleh dengan melonggarkan pengawasan terhadap Wajib Pajak, KPP sebaiknya memaksimalkan penerimaan pajak dengan terus meningkatkan kinerjanya dengan melaksanakan pelayanan yang terbaik, berupa memberi sosialisasi penyuluhan pemahaman tentang perpajakan di kantor, di masyarakat dan sebagainya sehingga mengurangi penyalah gunaan perpajakan atau bisa berupa layanan berbasis internet sehingga memudahkan masyarakat agar tidak perlu repot ke kantor pajak.

\section{DAFTAR RUJUKAN}

Faisal, E. (2016). Memahami Amnesti Pajak. (R. Akhiatri, Ed.) (Cetakan Pe). Jl Panjang, Kedoya Utara, Kebon Jeruk Jakarta Barat: PT Buku Pintar Indonesia. https://doi.org/9786021097243

Hadi, S. S., \& Bindura, R. T. (2018). Pengaruh Pelaksanaan Pengampunan Pajak (Tax Amnesty) Terhadap Penerimaan Pajak Pada KPP Pratama Jakarta Cengkareng, V(1).

Istighfarin, Nabila. 2018. Tax Amnesty dari Perspektif Masyarakat Pajak. Jurnal Akrual, 9(2), 142-156.

Kotler, Philip dan Keller, L. K. 2006. Metodologi Penelitian: Aplikasi Dalam Pemasaran, Jakarta: Indeks

Ngadiman dan Daniel Huslin. 2015. Pengaruh Sunset Policy, Tax Amnesty, dan Sanksi Pajak Terhadap Kepatuhan Wajib Pajak. Jurnal Akuntansi, 19(2): 225-241.

Muzammil, C. (2016). PEDOMAN PRAKTIS MEMBAYAR PAJAK. (C. Muzammil,

Ed.) (Cetakan-1). Ruko Gaharu Residence No.B3A-B6 J1 Kramat 3, Sukanti, Tapos, Depok: Genesis Learning. 
Pravasanti, Yuwita Ariessa. 2018. Dampak Kebijakan dan Keberhasilan Tax Amnesty Bagi Perekonomian Indonesia

Putra, I. M. (2017). PERPAJAKAN. (N. Lestari, Ed.) (tax amnest). J1 Imogori Barat km 4,5 No 95 Randubelang, Bangunharjo, Sewon, Bantul: QUADRANT. https://doi.org/978602-6595-37-9

Siahaan, M. pahala. (2017). Tax Amnesty Di Indonesia. (M. P. Siahaan, Ed.) (Cetakan-1). Jl Raya Leuwinanggung No.112. Kel Leuwinnanggung, Kec. Tapos Depok 16956: PT RAJA GRAFINDO PERSADA.

Republik Indonesia. PMK No.118/PMK.03/2016.Pengampunan Pajak.

Republik Indonesia. Peraturan Direktur Jendral Pajak PER-11/PJ/2016 subjek pengampunan pajak.

Republik Indonesia. Undang-Undang Nomor 11 Tahun 2016 tetang Pengampunan Pajak.

Http:www.pajak.go.id diakses tgl 24 Mei 2018 